\title{
A utopia concreta de Gonçalves Correia: Percurso e contexto de um anarquista alentejano singular
}

\author{
The concrete utopia of Gonçalves Correia: \\ The contexto and route of a singular alentejano anarchist
}

\author{
João Carlos Louçã \\ Doutorando em Antropologia pela Universidade Nova de Lisboa \\ joao.louca@gmail.com
}

\begin{abstract}
Resumo: Nas primeiras décadas do século passado, Portugal viveu períodos conturbados com a instauração da República e um proletariado, que apesar de essencialmente rural, descobria caminhos para a organização de classe ao mesmo tempo em que sonhava com uma sociedade mais justa. Anarquistas e sindicalistas, a sua influência perdurou e permite ainda olhar para esses momentos como fundadores de muitas das práticas emancipadoras que sobreviveram ao século XX e sobrevivem ainda. António Gonçalves Correia foi protagonista desse tempo e dessas lutas. A sua vida cruza-se com a história do movimento operário português. Na sua radicalidade libertária tenta uma vida comunitária e a comuna que fundou no Alentejo, teve um papel preponderante na resistência dos trabalhadores rurais durante a greve geral de novembro de 1918. A educação operária, os princípios da solidariedade e da igualdade, a autoorganização dos trabalhadores foram elementos fundamentais do seu pensamento e percurso.
\end{abstract}

Palavras-chave: Portugal. Primeira República. Anarco-sindicalismo. Comunitarismo. Utopia.

Abstract: In the first decades of the past century, Portugal lived through turbulent times with the implementation of the Republic and with a proletariat, that was essentially rural, that discovered the paths for a class organisation while, simultaneously, aspiring for a more just society. The influence of both anarchists and unionists lasted and are perceived as founding various emancipatory practices that survived the 20th century and still live on today. António Gonçalves Correia was a leading figure of that time and of those struggles. His life meshes and entwines with the history of the Portuguese labour movement. In his libertarian radicality he attempts a community life and the commune founded in Alentejo, had a determining role in the resistance of the rural workers during the general strike of November 1918. The workers education, the principles of solidarity and equality, the auto-organisation of workers were essential elements of his thought and his path.

Keywords: Portugal. First Republic. Anarcho-syndicalism. Communitarianism. Utopia.

Originais recebidos em: 19/03/2014

Aceito para publicação em: 17/07/2014

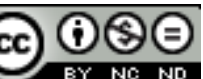

Este trabalho está licenciado sob uma Licença Creative Commons Atribuição-Uso NãoComercial-Vedada a criação de obras derivadas 3.0 Unported License. 
Há temas que a modernidade aparente parece ter feito entrar para lugares de visibilidade e debate social. Há recentes movimentos sociais que parecem ocupar o espaço dos anteriores, há preocupações que mobilizam pessoas e grupos e que aparentam ser novíssimos resultados do século XXI. Mas esta perceção pode revelar-se errada quando lhe procuramos os antecedentes e quando olhamos a história do movimento operário e encontramos afinal exemplos da sua afirmação nos momentos que implicaram as vidas de homens e de mulheres de outros tempos.

Portugal na viragem do século anterior, na agonia da monarquia terminada a 5 de outubro de 1910 - ao mesmo tempo que o Orpheu se publicava e o movimento modernista juntava, entre outros, Fernando Pessoa, Mário de Sá Carneiro, Almada Negreiros, Bordalo Pinheiro e ainda António Ferro; Portugal fundiário nas mãos de uma aristocracia decadente; Portugal de reduzidos focos de industrialização e falho daquilo que se considera genericamente sinal de modernidade; Portugal titubiante sem visível projecto de modernização do capitalismo que correspondesse a uma classe suficientemente forte para o protagonizar; Portugal periférico na Europa e dependente das relações externas, em particular de Inglaterra, na economia, na política e na moral; Portugal com uma enorme massa de explorados, proletários dos campos mais do que das cidades, que apesar de todas as probabilidades, se erguiam nas formas de organização e de apreensão do mundo, no esforço de alfabetização e de educação, na capacidade de luta. Nesse Portugal podemos encontrar causas que, afinal, não surgiram agora e que fazem parte do património de luta e da consciência crítica da emancipação proletária.

No projecto inacabado de Raul Brandão de retratar a humildade do povo português no livro "Os Operários" (1984), o repórter/escritor parecia querer organizar este seu contributo de análise da classe operária portuguesa e das suas realidades, através das pessoas que entrevistou e que representavam as organizações de classe que nesses anos de 1922/23 exerciam influência no movimento operário e popular do país. Antes mesmo das suas notas sobre os tanoeiros, trapeiros, caldeireiros ou os trabalhadores dos fornos de $\mathrm{cal}^{1}$, Raúl Brandão entrevista sindicalistas, dirigentes políticos, pessoas com papéis relevantes nos movimentos que representavam as várias correntes que, à época, partilhavam influência e capacidade de organizar as classes

\footnotetext{
${ }^{1}$ O Projeto de Raul Brandão tinha como título genérico "A Vida Humilde do Povo Português" e era composto por quatro textos diferentes: "Os Pescadores", "Os Lavradores", "Os Pastores" e "Os Operários". Só este último foi publicado em 1984, depois de um trabalho de recuperação a partir dos manuscritos do autor feito por Túlio Ramires Ferro que organizou e comentou a edição aqui utilizada.
} 
trabalhadoras de um país atrasado e dilacerado pelas guerras internas da $1^{\mathrm{a}}$ República, pela participação desastrosa na guerra mundial, pela pneumónica e pela pobreza. Através destas entrevistas, Raúl Brandão dá-nos um panorama dos debates internos entre a organização comunista nascente, o anarco-sindicalismo dominante na organização dos trabalhadores, os socialistas a quem o peso político em muitos dos momentos da $1^{\text {a }}$ República estava longe de corresponder a uma presença significativa e capacidade de organização das massas trabalhadoras. Entre estes entrevistados está António Gonçalves Correia, anarquista tolstoiano, cujas ideias e palavras registadas por Brandão têm a capacidade e força de nos remeter para o presente. Visionário capaz de antecipar debates do futuro? Homem à frente do seu tempo ou elemento integrante de uma corrente particular que foi primeiro vencida e depois esquecida pelos ventos do século XX? Exemplo de exceção ou exemplo de um protagonista singular no contexto português, que corresponde a uma linha de pensamento integrante da esquerda mundial e dos projetos de emancipação que atravessaram o século XIX, o XX e que são ainda capazes de atormentar tanta gente e de dar esperança a muita mais?

Nenhuma resposta é fácil nem óbvia, nenhum caminho está isento de contradições e de lapsos, nenhuma investigação pode responder de forma absoluta e afirmar que a histórica é mais do que um exercício de recolha de dados, interpretação e crítica. A verdade dos factos não nos esclarece sobre as intenções das pessoas em retrospetiva e a sua seleção, de que faz parte a actividade do historiador, deixa de fora os elementos considerados não relevantes numa escolha legítima, mas sempre orientada subjetivamente. Na subjetividade destas escolhas reside a força das interpretações que podem sustentar as teorias que olham o presente e a vida das sociedades nos seus percursos. Na actividade crítica dos conhecimentos adquiridos podemos encontrar fragmentos que completem o mosaico da história do movimento operário português, das mulheres e homens que o protagonizaram (na maior parte das vezes sem a história ficar sequer com o registo do seu nome), das suas aspirações e desejos mais profundos, das suas lutas diárias e das extraordinárias realizações de que foram capazes.

\section{Um rebelde consciente}

Quem frequentou as ruas de Beja nos início dos anos 60, lembra-se dele - "velho de barbas e cabelos compridos na sua bicicleta" (Bicho, 2012). Era daquelas figuras das 
cidades capazes de surpreenderem por parecerem não fazer parte do contexto, por se diferenciarem das restantes pessoas nas atitudes e naquilo que diziam, na forma como vestiam e nas relações que criavam. Já velho na época, Gonçalves Correia tinha passado pelas prisões da polícia política do Estado, tinha visto os sonhos da sua vida destruídos, tinha acalentado projetos fracassados e vivia em pleno regime onde a liberdade era vigiada, a organização dos trabalhadores reprimida e o autoritarismo reinava. O militante anarquista - conta quem se lembra de o ver - comprava pássaros nas feiras do Alentejo para depois os devolver à liberdade para gáudio das crianças que o acompanhavam delirantes neste jogo em que gritava entusiásticos vivas à liberdade. Vem a morrer em 2 de dezembro de 1967, numa casa de saúde de Carnaxide, na região de Lisboa, vítima de derrame cerebral. O Diário do Alentejo de 27 de dezembro, desse ano, assinala que a sua morte teve um profundo impacto na população da cidade de Beja. Realçava ainda o mesmo jornal a propósito do falecido ser este um homem de inteligência e cultura, ideias generosas a que se manteve sempre fiel. (FRANCO, 2000). Mais explícito e usando menos dos eufemismos que na época procuravam afastar a censura, em artigo de opinião no mesmo jornal o advogado António Batista Candeias escreve sob o título "Um homem bom que desapareceu":

Gonçalves Correia lutou contra um presente adverso, apenas com as armas da
eloquência e da bondade. Viveu apaixonadamente o mais belo ideal de
fraternidade humana. (...) Se há surdos e cegos que não ouvem nem vêem
tanto pior para eles. Os verdadeiros apóstolos vivem no mundo que sonham.
Por isso parecem loucos e morrem, quantas vezes, às mãos dos que
pretendem salvar. (...) António Gonçalves Correia nunca aceitou a derrota. O
amor, a liberdade, a igualdade, conceitos velhos e puídos pelo tempo, eram
palavras que na sua boca se imbuíam de uma nova dimensão e adquiriam
timbre jovem. (DIÁRIO DO ALENTEJO, 1967 apud FRANCO, 2000, p.60)

Nasce a 3 de agosto de 1886, em São Marcos da Ataboeira, uma das cinco freguesias do concelho de Castro Verde, que o censo de 1890 indica ter 571 habitantes. Segundo carta do próprio ao Presidente da República (A BATALHA, 21 de maio de 1920), foi republicano dos 18 aos 25 anos, libertário a partir dos 25 e por isso "acusado de inimigo da sociedade e da ordem". No mesmo texto, onde Gonçalves Correia que se encontrava preso, afirma-se "proletário do comércio". Desenvolvia actividade de caixeiro-viajante - como se designava nessa altura a profissão de vendedor percorrendo cidades, vilas e aldeias do Alentejo e Algarve. Nestas digressões vendia mercearias, madeiras e cordoaria. Talvez essa prática profissional justificasse o amor que tinha à sua bicicleta que decorava com um cartão na traseira em verso: "Diz o Gonçalves Correia/Que o mundo pisa os trilhos (vai tudo bem)/Para não lhe roubarem 
isto (a bicicleta) / Que é o pão dos seus filhos" (Bicho, 2012). Sem dúvida que esta actividade errante, lhe abriu portas para um outro conhecimento do país e da região, para a actividade de organizador e para a propaganda das suas ideias que considerava um dever militante fundamental. "Chapéu de aba larga descaído sobre a testa, barba negra a cair ao longo do peito (...) calcorreava todas as estradas poeirentas da região alentejana", segundo as palavras de Artur Modesto, sapateiro e anarquista de Beja (VOZ ANARQUISTA, 1977 apud FRANCO, 2000, p.29), Numa dessas viagens conhece a mulher com quem viria a casar em 1906, Ana de Jesus, filha de um rico comerciante de Portimão.

Em 1916 fixa-se na vila de Cuba onde funda o jornal “A Questão Social”. No cabeçalho uma frase de Guerra Junqueiro: "Há mais luz nas 24 letras do alfabeto do que em todas as constelações do firmamento" (A QUESTÃO SOCIAL, 1916 apud FRANCO, 2000, p.33) resumia assim o objetivo do jornal semanário que editou durante 12 edições e onde escreveu com regularidade. O objetivo da educação e esclarecimento das massas era fundamental para Gonçalves Correia e para muitos dos militantes anarquistas da época que consideravam que a política também se refletia na vida privada e nos domínios do quotidiano. Esta é uma das particularidades do seu pensamento que o pode aproximar dos nossos dias e da análise de movimentos sociais por muitos considerados como novos sujeitos. O vegetarianismo e a alimentação saudável, o respeito pela dignidade dos animais, o combate ao alcoolismo e ao tabagismo, considerados vícios perniciosos dos trabalhadores e ainda, a ideia de amor livre e com ela do casamento como farsa resultante da ausência de moral da sociedade burguesa que aprisiona as relações entre as pessoas transformando-as em contratos materiais sem justificação na realidade das emoções humanas (CORREIA, 1917). Em suma, uma moral própria, muito crítica das ideias dominantes da época e dos seus reflexos nas culturas operárias e camponesas. Uma ética que conjugava a ideia de sociedade sem classes onde a propriedade privada deixasse de ter lugar, com a absoluta radicalidade de um mundo novo que era necessário construir desde então, sem cedências ou compromissos. No artigo de apresentação da primeira edição de "A Questão Social”, Gonçalves Correia deixa claro que

o nosso jornal é para afastar o ódio e proclamar a harmonia. Mas o nosso jornal, porque à Verdade se quer sujeitar, terá de dizer muita coisa que não agrade a certos magnates nacionais e estrangeiros. (CORREIA 1916 apud FRANCO, 2000, p.33) 


\section{Um país à beira de um ataque de nervos}

Na biografia de Gonçalves Correia há um momento fundamental que condensa de certo modo o seu percurso militante e a sua ligação aos acontecimentos que marcaram a história da $1^{\text {a }}$ República debaixo do governo de Sidónio Pais: a tentativa de greve geral de novembro de 1918. Para alguns historiadores esta foi uma tentativa de insurreição (TELO, 1977) resultado da hegemonia perdida dos socialistas e do anarquismo moderado na União Operária Nacional (UON). Constitui uma derradeira tentativa das direções sindicais mais radicais, então maioritárias, de contrariarem o rumo dos acontecimentos na que terá sido a primeira manifestação revolucionária autónoma do proletariado em que este enfrenta o poder de Estado sem se deixar conduzir pelas classes dominantes, como até então tinha feito nos golpes e contragolpes que instituíram a $1^{\text {a }}$ República.

Olhemos ligeiramente para trás. A teia produtiva do país em 1911, um ano depois da proclamação da República era, segundo os censos desse ano, composto por $55 \%$ de trabalhadores agrícolas, $21 \%$ de trabalhadores nas indústrias e 5\% no comércio. Uma grande maioria da população vivia nos espaços rurais e mesmo os $21 \%$ de trabalhadores na indústria, eram na sua grande maioria pessoas que trabalhavam em indústrias artesanais, em pequenas oficinas tradicionais. A industrialização pensada enquanto processo de modernização da sociedade e de nova organização do trabalho em regimes associados ao fordismo e taylorismo só viria a acontecer depois e em pólos muito reduzidos de implantação. Só a região de Lisboa, a península de Setúbal, Covilhã e Porto é que puderam ver esse processo de industrialização que em Portugal foi tardio e largamento incompleto.

Na manhã de 5 de dezembro de 1917, tropas começaram a juntar-se no alto do Parque Eduardo VII, em Lisboa. É o fim do governo de Afonso Costa e do Partido Democrático para o que foi fundamental a revolta generalizada face à carestia de vida provocada pelo esforço da participação do país na Guerra Mundial. Afonso Costa é preso e o presidente da República Bernardino Machado expulso do país. Com sinais contrários, a afirmação dos primeiros momentos do novo governo é a procura de um espaço de consenso entre realidades inconciliáveis, entre interesses populares e dos trabalhadores, e as movimentações do restauracionismo monárquico, entre a aspiração de paz que determinou o apoio ao golpe para grande parte da população e a instauração 
de um regime musculado, feito da construção de uma imagem mistificada de homemprovidencial, iluminado e capaz dos maiores feitos.

Pragmático, o embaixador britânico dirige-se logo de manhã ao chefe das tropas revoltosas para garantir o seu total apoio no caso de uma vitória. Afonso Costa ficava assim mais isolado e Sidónio Pais, de quem corriam rumores de ser germanófilo, ficava amarrado aos compromissos militares e comerciais do Estado com a Inglaterra.

A participação da UON neste golpe dá-se quando um grupo de seus dirigentes se dirige a Sidónio, ainda no Parque Eduardo VII, e lhe pede a libertação de presos políticos. Este resiste à exigência num primeiro momento mas cede e na verdade essa é uma das primeiras medidas executadas pelo novo governo. Provavelmente por este ato profundamente significativo para as direções operárias, ou porque na crítica à participação portuguesa na guerra foi o movimento popular que convergiu com o momento do golpe, o que é facto é que a alteração política foi recebida com agrado. Afonso Costa, conhecido por "Racha Sindicalistas", era inimigo declarado e a sua capacidade de resposta ao golpe militar foi impossibilitada pela população que saiu à rua e impediu as tropas de se movimentarem. O sentimento popular era de esperança e Sidónio protagonizou esse sentimento num primeiro momento. Poucos dias depois na imprensa operária, responsáveis e dirigentes da UON referiam-se ao governo da Junta instaurado pelo golpe com expetativas positivas. A sua aclamação inicial pelas massas seria rapidamente transformada em divórcio entre o regime e a população trabalhadora.

Considerado por muitos, um regime que antecedeu e preparou do ponto de vista ideológico o golpe militar de 28 de maio de 1926, Sidónio Pais constituiu-se como precursor das formas autoritárias que se generalizariam nove anos depois. A figura providencial de chefe austero, sempre na sua farda militar, agradava à direita conservadora e aos republicanos que queriam ordem e disciplina. É num projeto legislativo deste tempo que podemos encontrar o embrião da organização corporativa que viria a ser instaurada, mais tarde, pelo regime do Estado Novo.

A ilusão de Sidónio dura pouco. A imagem mítica de salvador da pátria e unificador das diferentes correntes políticas, não pôde resistir à realidade de um país empobrecido e em que as classes dirigentes se dividiam entre uma burguesia essencialmente republicana e proprietários fundiários afetos à monarquia. As tréguas de Sidónio com a Igreja católica, voltando a incorporar os seus rituais nas ocasiões de Estado, não podiam agradar a muitos republicanos e à Maçonaria em particular. Por outro lado, a perseguição que moveu contra organizações e dirigentes operários, não 
sendo uma novidade, determinou o afastamento definitivo das esperanças nele depositadas, num primeiro momento, pelas massas trabalhadoras. Os seus partidários resolvem criar um partido à sua medida, o PNR, que durante o seu governo foi dirigido pelo Nobel da medicina Egas Moniz e que pretendia ser chapéu de chuva das várias opções políticas que se reuniam à volta do chefe de Estado. Contudo, esta pretensão de olhar para a sociedade através da afirmação de que um único partido seria preferível do que formas de democracia representativa pluripartidária, não vingou naquele momento. Viria a ser instaurada 8 anos depois, através de uma golpe militar que mergulha o país no autoritarismo reacionário durante 48 anos. E nem a participação de Sidónio no "seu" PNR estava assegurada, uma vez que viveu o seu breve consulado governativo na ilusão de manter atuante as forças circunstanciais que o transportaram ao poder.

Com a morte trágica de Sidónio Pais, a sua figura é criada e recriada. Santo para uns e tirano para outros, há um processo de transfiguração no que Fernando Pessoa chama de "Presidente-Rei" (SAMARA, 2002).

\section{A greve geral falhada de novembro de 1918}

Marcada pela UON para o dia 18 de novembro, a greve surge como resposta ao agravar da situação social e do aumento da repressão face às organizações de classe e a todas as formas de contestação. O exemplo da revolução soviética colocava a tomada do poder na ordem do dia. Quando um país igualmente atrasado, igualmente agrário na grande maioria do seu tecido produtivo, mas com pólos importantes de indústria e uma direção proletária radical, vivia uma situação revolucionária, esta influenciava e dava esperança aos trabalhadores de todo o mundo. Mas Portugal não era a Rússia, nem as frágeis direções operárias tinham a mesma experiência que os bolcheviques de 1917. Seja como for, os exemplos dessa influência são numerosos. Desde logo pela voz de quem vivia no terror do alastramento da experiência soviética. Brito Camacho, Ministro do Interior, reflete esse pânico quando garante, a poucos dias da greve geral que já existem sovietes em Lisboa. A imprensa burguesa multiplica-se em ataques à revolução russa em medida preventiva contra a possibilidade do seu contágio em Portugal. Mas esse contágio crescia à medida que a revolução avançava e se consolidava na Rússia. Nas vésperas da greve geral, a possibilidade de um levantamento popular, dirigido pelas organizações de classe dos trabalhadores estaria no espírito dos seus principais 
responsáveis. Em março desse ano, vários grupos libertários distribuíam propaganda em que a revolução russa era dada como exemplo a seguir. O jornal "A Greve" garante aos eleitores que se aproxima a "grande revolução" e solta vivas à revolução na Rússia. Numa reunião do sindicato da construção civil fazem-se incitamentos à formação de sovietes e à revolução social como única solução para a situação portuguesa. A corrente radical que então dirige a UON encara a perspectiva de uma "implantação de sovietes à russa" (TELLO, 1977; ROSAS, 2009).

Contudo, as reivindicações imediatas da greve são o aumento generalizado de salários, a recusa da participação dos trabalhadores no Senado corporativo da nova Constituição sidonista e a solidariedade com os trabalhadores presos. A onda repressiva desse ano foi brutal. Em abril, 28 mineiros são presos em São Pedro da Cova. Em junho, durante uma greve de ferroviários os militares ocupam as instalações e obrigam os grevistas a retomar o trabalho. Na Primavera, poucos meses depois de a ter abolido, Sidónio restabelece a censura na imprensa operária e atribui poderes totais à polícia nos mandatos repressivos. Em agosto, depois de uma greve prolongada na construção civil, os trabalhadores conquistam as oito horas de trabalho diário. Até então trabalhavam dez horas. Em setembro a polícia proíbe os comícios da UON e esta começa a ser alvo de uma brutal repressão o que vem reforçar a sua corrente interna mais radical. A 14 de outubro o governo declara o estado de sítio e no dia 13 de novembro o sidonismo organiza uma manifestação dita espontânea de regozijo pelo final da guerra, mas efetivamente de apoio ao regime. Nela há relatos de gritos de "Viva a Rússia livre! Viva a pátria Universal! Viva Lenine! Abaixo o exército!" (TELLO, 1977)

À escala nacional a greve falhou em toda a linha. Falhou como paralisação geral do país e falhou os seus objetivos de despoletar uma situação revolucionária. Só na região de Lisboa o governo executa 300 prisões preventivas entre os quais estão os principais dirigentes operários comprometidos com a greve. Na resposta repressiva do governo a acusação era de que os grevistas queriam promover sovietes, a desorganização e o saque. Como resultado imediato, mais de mil prisões, inúmeros despedimentos, a dissolução administrativa de sindicatos e uniões federativas mais combativas: a UON, a Federação da Construção Civil, a Federação dos Sindicatos Operários de Sul e Sueste, Associação dos Tipógrafos, entre outras. Por outro lado, os efeitos da gripe pneumónica que, na época, dizimava as classes populares em toda a Europa e se faziam sentir com bastante intensidade também em Portugal, terão sido 
determinantes no fracasso do movimento grevista ${ }^{2}$. O erro da direção operária foi pensar que este era um elemento que reforçava a luta ao mesmo tempo em que tornava mais precárias e difíceis as condições de vida do proletariado. A influência católica terá sido determinante para deslocar as possibilidades de luta para um plano de resignação místico onde a política da revolução não podia ter lugar. Lembremo-nos do "milagre de Fátima", em maio de 1917, e da sua enorme influência ideológica num país atrasado e profundamente religioso.

Para mais, o armistício assinado entre os Aliados e a Alemanha tinha posto fim à guerra e com ela à participação portuguesa a escassos sete dias da greve geral. A Europa suspirava, vivia momentos de esperança que aqui também se faziam sentir e que ao mesmo tempo aliviam a pressão social sobre o governo de Sidónio Pais e as suas políticas.

A 20 de Novembro, nova parada militar em Lisboa de apoio ao governo, as massas saíram à rua em nome da "família, do lar e da Pátria" e contra a "anarquia e a subversão" (TELLO, 1977). A hipótese de greve geral que conduzisse a uma situação de insurreição pré-revolucionária estava enterrada.

\section{A greve geral no Alentejo}

Consideravelmente importante a influência anarquista entre os trabalhadores rurais alentejanos, a sua organização sindical centrava-se em torno das estruturas da União Operária Nacional (UON). Se o liberalismo pôde determinar o final do antigo regime de concentração de propriedade e de relações medievais na exploração da mãode-obra camponesa, verificamos uma transferência paulatina de propriedades das mãos da aristocracia para uma burguesia com interesses económicos diversificados. Por outro lado, o estatuto dos trabalhadores e o seu controlo da propriedade manteve-se inalterado com o advento da República, sobretudo no Alentejo onde o modelo da propriedade era o latifúndio. A relativa modernização dos processos de produção agrícola com a introdução de vários instrumentos que intensificavam a produção e rentabilizavam a mão-de-obra, veio reforçar taxas de lucro e mecanismos de exploração intensivos, das terras e das pessoas que nelas trabalhavam. Em agosto de 1913, o governo introduz a

\footnotetext{
${ }^{2}$ Entre 1917 e 1918 as epidemias de tifo e de pneumónica (também designada por "gripe espanhola") mataram entre 20 a 40 milhões em todo o mundo. Calcula-se que em Portugal mais de 100 mil pessoas morreram devido a estas doenças neste período.
} 
"Lei dos Baldios" que oferece terras tradicionalmente dedicadas ao uso comunitário para as mãos de proprietários privados, no que seria um ataque sem precedentes a formas de vida ancestrais de populações que deixavam de ter maneira de subsistir para além do trabalho à jorna. Estavam reunidas as condições para a organização de trabalhadores, proletários rurais sem terra própria nem contratos permanentes, com horários de trabalho intensivos e salários baixos.

Em 1914 os trabalhadores rurais de Odemira faziam parte da Federação Nacional dos Trabalhadores Rurais que, por sua vez, integrava a UON. Entre 1914 e 1916 desenvolvem vários processos de luta, comícios e ações de propaganda. É no Vale de Santiago, uma das freguesias do concelho de Odemira, que os conflitos são mais intensos. Em particular um momento em que os trabalhadores são fortemente reprimidos, julgados e condenados a 40 meses de prisão maior. Estes trabalhadores viriam a ser libertados em consequência do golpe de Sidónio.

Como tantos outros trabalhadores antes de si, em luta contra a carestia de vida e a fome, no Vale de Santiago, por esta altura os trabalhadores decidem impedir a saída de géneros do concelho e obrigar a sua venda às populações. Estas formas de "economia moral", de controlo da produção e distribuição de alimentos, foram sempre negadas pelos proprietários que utilizaram a força repressiva da Guarda Nacional Republicana (GNR) acusando os trabalhadores de assaltos e vandalismo. Refletindo sobre a realidade das lutas sociais dos trabalhadores alentejanos no virar do século XIX, Pacheco Pereira refere,

Antes das greves de 1921-11, a criminalidade e o banditismo assumem a manifestação mais saliente da luta dos trabalhadores rurais, assumindo principalmente as formas de roubo, da violência contra a propriedade (fogo posto em particular), da vadiagem, da violência contra pessoas (agressão e homicídio). (PACHECO PEREIRA, 1979, p. 135).

No mesmo trabalho, refere os acontecimentos de 1918 no Vale de Santiago considerando estas formas de violência um

meio de resistência e de defesa e forma ofensiva no terreno da luta de classes. (...) A propriedade nunca foi sacralizada no Alentejo. As primeiras greves de 1910-11 e incidentes isolados como os de Odemira em 1918, revelaram a interligação entre estas formas primitivas de ação social e as formas mais modernas como a greve e a luta sindical, e que elas se podiam fundir (PACHECO PEREIRA, 1979, p. 155).

Em diversos momentos, até meados de 1918, a população do Vale de Santiago obrigou proprietários e autoridades locais e abrirem os seus armazéns e colocarem nos mercados locais os seus produtos a preços impostos e controlados em assembleias 
populares. Em junho de 1917, as associações impõem aos proprietários agrícolas formas de contrato coletivo de trabalho com aumentos na ordem dos $100 \%$ em todas as freguesias do concelho. No Vale de Santiago, os proprietários recusando-se a pagar os salários acordados, recorrem a mão-de-obra algarvia e à GNR para conseguir impor a medida, conseguindo ainda a dissolução da Associação de trabalhadores. Havia por isso condições para a adesão entusiástica de trabalhadores desta região ao projeto de greve geral decretado pela UON para 18 de novembro de 1918. Como aconteceu, aliás, no conjunto dos distritos de Beja e Évora onde a adesão à greve foi generalizada (CANAIS ROCHA et al, 1982).

Foi daqueles momentos da história que são confundidos pelo quadro geral. Este foi de derrota inequívoca e de falta de comparência generalizada dos proletários dos campos e das cidades ao apelo da greve. Mas no Vale de Santiago, os trabalhadores aderiram com entusiasmo e fizeram aquilo que melhor sabiam e que a sua experiência anterior tinha demonstrado dar resultados: pararam a produção, arrombaram armazéns, distribuíram bens de primeira necessidade e ocuparam terras. Claro que o facto de terem sido uma excepção resultou na sua derrota inevitável face ao assalto da GNR. O falhanço generalizado da greve condenou os trabalhadores do Vale de Santiago ao isolamento e à ausência absoluta de condições de resistência.

No dia 22, depois de quatro dias de euforia e luta em que os trabalhadores ocuparam terras e distribuíram trigo açambarcado nos armazéns, um grupo de cerca de 60 homens armados de caçadeiras concentravam-se no ponto mais alto da aldeia, o Cerro Alto, onde esperavam resistir ao assalto da GNR, depois desta ter já fechado a sede da Associação dos Trabalhadores Rurais e feitos diversas prisões. Segundo depoimento, de um participante ativo nos acontecimentos, concentraram-se ali os trabalhadores resistentes não só daquela freguesia mas também de outras vizinhas. Uma força a cavalo da GNR que integrava grupos de civis armados contra os insurrectos consegue vencer a resistência e pôr o grupo em debandada. Inicia-se a perseguição que viria a dar origem à prisão e deportação para Luanda, em Angola, de cerca de 30 ativistas, sem julgamento ou culpa formada - "deixaram lá uma avenida de Luanda feita por eles" (CANAIS ROCHA et al, 1982).

Sem ter participado diretamente nestes acontecimentos, Gonçalves Correia é preso em Beja, condizido à cadeia do Limoeiro em Lisboa, acusado de se ter apossado de adubo indevidamente. Com efeito, o anarquista é figura incontornável deste ambiente onde trabalhadores rurais ensaiavam formas de organização e luta, parte ativa de uma 
classe que tomava consciência de si própria e das suas capacidades para mudar o mundo. A acusação é falsa e Gonçalves Correia é libertado pouco depois. Mas a sua Comuna da Luz viria a ser desmantelada pelo mesmo movimento de tropas e civis armados que venceram os homens do Cerro Alto. Acusada de ser um refúgio de anarquistas e comunistas, o revanchismo dos homens da situação destruiu as instalações, prendeu quem encontrou e agrediu violentamente mulheres e homens que lá se encontravam. Confessa Gonçalves Correia a Raul Brandão, interpretando anos depois estes acontecimentos com a mágoa de terem determinado o fim do projeto de vida comunitária que ali ensaiou:

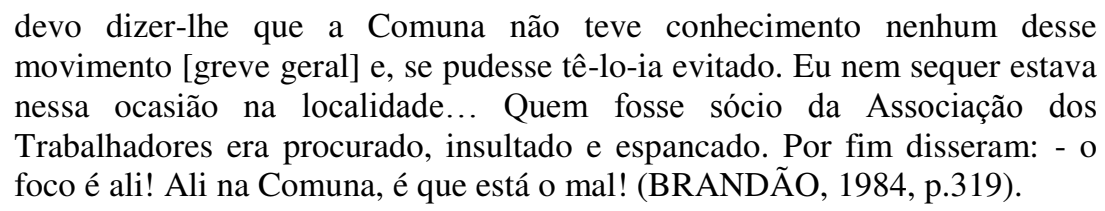

Uma conclusão parece impor-se: a da influência de Gonçalves Correia e da Comuna da Luz no decorrer dos acontecimentos que levaram os trabalhadores do Vale de Santiago a aderir à convocatória da greve geral, a ocuparem terras e sonharem com um mundo em que o seu trabalho não mais fosse garantia de acumulação de riqueza dos patrões.

\section{José Júlio da Costa}

Nestes acontecimentos de novembro de 1918, destaca-se um personagem: José Júlio da Costa, 25 anos, ex-sargento do exército e condecorado após duas comissões em África. Voluntário para o exército com 16 anos, participa na instauração da República a 5 de outubro de 2010, ao integrar um dos regimentos cruciais para o lado republicano. No Vale de Santiago fazia parte da elite local através do casamento com uma rica herdeira da região, tendo sido nomeado presidente da Junta de Freguesia, após ter sido recusado pela embaixada de França onde se tinha ido oferecer como voluntário para combater contra a Alemanha. No momento do assalto a Cerro Alto integrou a força da GNR a cavalo e teve um papel que ainda hoje não é claro. A versão mais reproduzida garante que teve um papel de mediador em que tentou uma rendição dos sublevados e garantir a sua segurança posterior. Para esta versão, José Júlio teria sido um personagem equilibrado que tinha procurado evitar um banho de sangue e as represálias que se viriam a abater sobre os grevistas. Aliás, terá sido este um episódio determinante na sua 
decisão de assassinar Sidónio Pais um mês depois, tendo-se sentido traído e ultrajado como negociador do Cerro Alto.

Mas outras versões dão-no como um partidário da repressão e um dos mais entusiastas na perseguição posterior à rendição. Inclusive, Gonçalves Correia também o cita na entrevista que dá a Raul Brandão e dá-o como presente na Comuna da Luz quando a professora primária que nela participa e que segundo Gonçalves Correia era a sua “alma", é insultada e agredida à coronhada. José dos Reis Sequeira, operário corticeiro, citado por João Medina conta a sua versão do comportamento de José Júlio da Costa:

Apareceu a cavalo e logo que a tropa se encontrava preparada para marchar, o José Júlio tomou a frente como guia para indicar o caminho da região rebelde, direção de Sta. Luzia. Ouviu-se depois dizer que andou com a Guarda pelos montes à caça dos cabecilhas da greve. Estes foram presos e deportados. (MEDINA, 1994, p. 179, 180)

Esta versão parece ser confirmada pelo agente de polícia Manuel Alves Oliveira:

Pois o único civil que acompanhou a força armada para atacar os assaltantes... foi o José Júlio da Costa, tendo este pedido ao sargento Martins da Guarda Republicana, para fazer descargas cerradas para os ditos assaltantes e foi um dos que mais queria que matassem os chefes dos Sovietes (TEMPO, 1919 apud MEDINA, 1994, p. 180).

Mas, refere ainda João Medina, apesar deste indício, atribui-se a José Júlio da Costa simpatia pelo "anarco-bolchevismo". Manuel Ribeiro, aderente do maximalismo ${ }^{3}$, que o entrevistou na prisão para "A Batalha" escreveu que José Júlio lhe tinha assegurado ser

essencialmente um democrata que não recua ante os mais avançados ideais. Quero a democracia, não para cristalizar nela mas para que ela crie um ambiente novo e condições de viabilidade para o comunismo, que eu considero a meta ideal da felicidade (MEDINA, 1994).

A ambiguidade do personagem vai manter-se muito para além dos acontecimentos de novembro e ser obviamente parte do mito em torno do assassinato de Sidónio Pais. Viria a ser preso na Penitenciária de Lisboa. Em outubro de 1921 é libertado em consequência de uma revolta com pormenores sangrentos. Só em janeiro de 1927 volta a ser preso, em Matosinhos, por António Maria Fernandes, admirador de Sidónio Pais e funcionário público obscuro. Já com a polícia política a ensaiar os seus primeiros passos, José Júlio da Costa volta à Penitenciária de Lisboa de onde só sairá

\footnotetext{
${ }^{3}$ A Federação Maximalista Portuguesa, constituída em 1919 tinha como objetivo "difundir os princípios doutrinários tendentes ao estabelecimento do sindicalismo comunista, admitindo transitoriamente a ação do poder revolucionário exercido em ditadura pelos conselhos operários ou sovietes". Considera-se esta organização efémera ser o embrião do Partido Comunista que viria a ser fundado em 1921.
}

Em Debat: Rev. Dig., ISSNe 1980-3532, Florianópolis, n. 9, p. 90-111, jan-jun, 2013. 
para o hospital psiquiátrico Miguel Bombarda, aonde viria a falecer em 28 de janeiro de 1948. Dele diz-se que foi uma coisa e outra: apoiante do comunismo e verdugo dos trabalhadores, numa espécie de bipolaridade que será difícil confirmar. Diz-se ainda que foi protegido de Ana de Castro Osório, figura simpatizante do sidonismo e mais tarde, do Estado Novo. Maria Feio, outra sidonista convicta, que o visita na prisão, afirma-o arrependido de ter executado o homicídio do presidente. Mas, independentemente dos motivos que o levaram a executar Sidónio e do seu hipotético arrependimento posterior, a verdade do seu papel nos acontecimentos do Vale de Santiago está ainda por esclarecer. Sabemo-lo republicano, investido pelo regime de Sidónio Pais da responsabilidade da Junta de Freguesia, sabemo-lo ainda participante e provavelmente orgulhoso dessa participação no 5 de outubro de 1910, veria provavelmente com apreensão o regime de Sidónio que se apoiava e simultaneamente dava poder à Igreja e aos terra-tenentes partidários da restauração monárquica no seu Alentejo natal. Mas tudo isso são hipóteses com necessidade de confirmação, assim como a forma da sua participação nos acontecimentos da greve geral de novembro de 1918.

\section{A natural influência da revolução soviética}

Um parêntese pode ser aqui feito para clarificar os aspetos essenciais em torno da influência da revolução russa no movimento operário português e nas suas direções. Como vimos já, a hegemonia ideológica era fundamentalmente das correntes anarquistas. No final da segunda década do século XX, ao mesmo tempo em que a revolução dos sovietes lutava pela sobrevivência, o proletariado português, como provavelmente em todo o mundo, via com enorme expetativa e esperança $\mathrm{o}$ desenvolvimento da revolução de outubro na Rússia. Em introdução ao trabalho de Canais Rocha e Rosalina Labaredas, João Medina salienta que o

\footnotetext{
Alentejo era palco de revolucionárias reivindicações, espécie de modesto e longínquo eco luso dos decretos bolchevistas de novembro do ano anterior, abolindo o direito de propriedade privada da terra e concedendo a todos os trabalhadores rurais o uso das terras. (...) [o "sovietismo"] explica-se não só pelo alento imenso que à causa operária e rural vinha trazendo o "bolchevismo" (como então se dizia), mas ainda pela ingénua e confiante esperança do anarco-sindicalismo português numa revolução que julgava sua: os sonhos libertários e projeto leninista ainda não tinham chocado frontalmente (MEDINA, 1982 apud CANAIS ROCHA et al, 1982, p. 5).
}

Nesta análise o seu autor explica a adesão do anarco-sindicalismo ao projeto revolucionário soviético por uma espécie de engano provocado pela sua ingenuidade. 
Ora, a revolução soviética, nos seus primeiros anos, protagonizou muito provavelmente as aspirações e desejos de uma parte significativa do proletariado mundial. A divisão, que se viria a acentuar entre comunistas e anarquistas, em 1917 e 1918 não existia ainda em Portugal. Naturalmente, os militantes sindicais e políticos do anarquismo desses anos olhavam para a revolução russa e sentiam-na como sua. Claro que o divórcio de que fala Medina aconteceu mesmo e o processo da revolução determinou a exclusão de muitas das suas componentes libertárias que não se reviam no Partido Bolchevique e que, mais tarde, foram por ele perseguidas. Mas num primeiro momento as linhas de divisão eram até outras. Por exemplo, entre quem defendia a participação na guerra mundial e quem era radicalmente contra ela. Nesse último caso estavam uma boa parte dos anarquistas, no plano internacional subscrevendo a posição de Errico Malatesta assim como os partidários da Internacional Comunista - em Portugal era o caso dos militantes em torno dos jornais "Aurora" e "Sementeira". Favorável à participação proletária ao lado dos seus governos e contra a Alemanha, Pedro Kropotkine cujas posições eram representadas em Portugal pelo "Germinal". Ou seja, num tema essencial de definição política os militantes anarquistas estavam profundamente divididos à escala internacional e as formas de perceção a propósito da revolução russa não seriam indiferentes a esta linha definidora entre os partidários da guerra e os anti-guerristas. Nesta hipótese, os argumentos da ingenuidade defendidos por Medina não parecem colher. Provavelmente, Gonçalves Correia que era radicalmente contrário à guerra referia-se-lhe como "monstro infamíssimo" - estaria muito mais próximo dos militantes comunistas que se lhe opunham do que dos anarquistas que a justificavam.

O facto do regime político de Sidónio Pais e a burguesia utilizar a revolução Russa para diabolizar todas as tentativas de organização operárias e todas as lutas por direitos, usando o "bolchevismo" e o "sovietismo" como sinónimo de caos e destruição, tornava-a uma referência simbólica fundamental para esses processos de luta. Por outro lado, a ideia de sociedade sem classes e da revolução para instaurar uma sociedade comunista era partilhada entre militantes comunistas e libertários. O anarquismo do princípio do século XX reivindicava-se do comunismo e muitas pessoas flutuavam entre estas duas realidades ideológicas sem grande distinção, sem grandes barreiras práticas. Terá sido este o caso de Gonçalves Correia que, para além de ter participado na fundação da Federação Maximalista (com tantos outros militantes anarquistas), se dizia comunista, e por diferentes ocasiões olhou para a revolução soviética com a esperança 
dela poder ser um exemplo fundamental para a luta de emancipação dos trabalhadores em todo o mundo. A sua ficha incluída no ficheiro da PIDE/DGS ${ }^{4}$, apresenta-o como

um comunista perigoso, sendo considerado em todo o Alentejo como organizador e orientador de todos os movimentos de caráter social. Já esteve preso, por estar implicado nos tumultos sangrentos de 1918, em Beja sendo posto à disposição da $4^{\mathrm{a}}$ Divisão do Exército. É administrador de concelho maximalista, em Beja (CORREIA, 1932)

$\mathrm{Na}$ entrevista que realiza em Março de 1923 a um dirigente do Comité Nacional da União Anarquista Portuguesa, Raul Brandão pergunta diretamente, "São comunistas?", ao que o entrevistado responde, "Na sua grande totalidade são. Há alguns individualistas, mas muito poucos” (BRANDÃO, 1982, p.285). Nesta resposta, dada já depois da direção soviética ter reprimido violentamente os marinheiros em Kronstad, o termo "comunista" é associado à vida comunitária, contraposto ao individualismo, mais do que a uma ideologia do comunismo que era vigorosamente protagonizado naquele momento pela experiência soviética. É natural que para muitos dos anarquistas em Portugal a associação ao comunismo fosse essencialmente por esta associação a estilos de vida comunitários e às utopias de configuração social que estas representavam.

Noutro plano, o das referências utilizadas por Gonçalves Correia, no seu opúsculo "Estreia de um Crente" publicado em edição de autor em 1917, refere Louise Michel e Rosa Luxemburgo como exemplos semelhantes de combatividade e capacidade revolucionária na "carta a uma mulher" que começa com "minha senhora, camarada, irmã em crença". A sua "carta a um republicano" inserida em "Estreia de um Crente", Gonçalves Correia afirma-se "inimigo da monarquia em benefício da República, inimigo da fórmula republicana em benefício das teorias comunistas que são hoje a razão da minha existência" (CORREIA, 1917). No mesmo texto, o seu autor apresenta o "socialismo libertário" como alternativa ao "socialismo parlamentar" e refere os "mártires de Chicago" numa evidência de que as referências internacionalistas seriam partilhadas por libertários e comunistas do mundo inteiro.

Outro personagem desse momento de transição é Carlos Rates, que veio a ser primeiro secretário-geral do Partido Comunista. Dirigente operário do anarcosindicalismo, responsável pela reorganização da UON no Alentejo, confessa a Raúl

\footnotetext{
${ }^{4}$ Em 1932 Gonçalves Correia é preso e investigado por suspeita de divulgação de propaganda clandestina. Estando o registo desta prisão no ficheiro da PIDE, na Torre do Tombo, contudo a designação da polícia política do regime era, à época de Polícia Internacional Portuguesa. A PIDE só viria a ser instituída depois da Constituição do Estado Novo a partir de 1933. Gonçalves Correia viria a ser libertado poucas semanas depois e o auto registado pela Secção de Vigilância Política e Social da referida polícia.
}

Em Debat: Rev. Dig., ISSNe 1980-3532, Florianópolis, n. 9, p. 90-111, jan-jun, 2013. 
Brandão que ficou "bêbado [com a leitura] de Faure e o Kropotkine". Com a revolução russa e a forte influência que ela exerceu no seu espírito, torna-se um dos "sócios fundadores do Partido Comunista". Adiante, Carlos Rates refere ainda que

a CGT tem uma corrente que afirma ser inviável a ditadura do proletariado. Se, ao contrário, a CGT preconizasse essa ditadura, saída da própria organização sindical, o Partido Comunista não tinha possibilidades de se desenvolver" (BRANDÃO, 1984, p.297).

Curiosa esta afirmação, que ao mesmo tempo que salienta a divergência fundamental com os anarquistas (a ditadura do proletariado e não o objetivo final do comunismo), traduz em simultâneo a tradição de Rates associada ao anarco-sindicalismo. Este é entendido, não só como forma de representação de classe, mas também como organização política autónoma capaz de lutar pela revolução. Ao contrário de outros países onde ainda hoje perduram organizações sindicais com esta perspetiva globalizante, em Portugal ela não sobreviveu apesar de ser tão forte na época que estamos a tratar.

\section{Comuna da Luz, a utopia tornada concreta}

Em formas de organização prévia à sindical, que se viria a generalizar na representação de classe no virar do século, o mutualismo foi elemento incontornável para uma análise histórica dos percursos da classe trabalhadora e dos seus processos constitutivos enquanto setor autónomo da sociedade e com capacidade de se autorganizar. Como refere Marcel VanDer Linden (2008), o mutualismo não era exclusivo da classe trabalhadora, mas uma forma de diferentes grupos poderem partilhar trabalho, produtos e dinheiro. Como adianta este autor, esta era uma "importante componente das estratégias de sobrevivência do proletariado" (LINDEN, 2008, p. 82). Convergente com os interesses de reprodução da mão-de-obra e por isso também das classes dominantes, o mutualismo, em Portugal do século XIX era naturalmente influenciado por uma cultura católica que ostentava as formas de beneficência dos poderosos como a forma por excelência de redistribuição da riqueza. A sua generalização no seio operário veio colocar visível, pela primeira vez, a capacidade de autorganização e de gestão comuns de meios escassos. De natureza radicalmente diferente do sindicalismo de representação de classe e com o objetivo de lutar por direitos, o mutualismo foi seu precursor nessa capacidade dos trabalhadores tomarem consciência de si e dos seus problemas. Modalidades da sua sobrevivência podem ser 
observadas ao longo do século XX, não só na Europa mas um pouco por todo o mundo, fazendo parte da história dos movimentos populares e tendo, sem dúvida, deixado marcas na cultura operária.

Uma dessas influências terá sido a enorme preocupação com a educação dos militantes sindicais do virar do século XIX, que influenciou as formas de organização de classe que se verificaram posteriormente. Bastará fazer o levantamento em Portugal das Sociedades de Instrução Musical da Península de Setúbal, das muitas escolas de raiz mutualista onde os filhos dos trabalhadores podiam aprender a ler e a escrever ${ }^{5}$, das coletividades que nasciam localmente e tinham nas leituras coletivas de jornais o seu centro, das bibliotecas operárias, etc.

É neste enquadramento histórico que podemos olhar para um dos projetos mais queridos de Gonçalves Correia. A Comuna da Luz tinha como objetivo praticar "o comunismo máximo e adotando o lema «a cada um segundo as suas forças, e a cada um segundo as suas necessidades" (A GREVE, 1917 apud CANAIS ROCHA et al, 1982, p. 170-171).

Tratou-se da aquisição de uma parcela de terreno de cerca de 3 quilómetros quadrados, próximo da aldeia do Vale de Santiago, herdade das Fornalhas Velhas. Com cerca de quinze companheiros, entre os quais algumas mulheres e crianças reconstruíram as ruínas do casario, montou uma cozinha comunitária e organizou uma oficina de sapataria. Tendo fundado em simultâneo a escola Ferrer para as crianças da comuna, para além da atividade de produção e reparação de sapatos, dedicavam-se naturalmente à agricultura. Gonçalves Correia explica a Raul Brandão:

levantávamo-nos ao nascer do sol e trabalhávamos sempre: semeámos trigo, plantámos batatas, semeámos todos os vegetais. Água não havia, íamos buscá-la longe - mas resolvemos abrir um poço e, dentro em pouco, ajudados pelos trabalhadores dos arredores que nos viam com simpatia, tínhamos água excelente em abundância. (BRANDÃO, 1984, p. 317)

A experiência da Comuna da Luz durou cerca de dois anos e exerceu certamente uma influência grande no proletariado agrícola da região que via aquela comuna como um exemplo de autoprodução e libertação das amarras do patronato. Não é por acaso que as redes de solidariedade da Comuna vão bastante além das relações dos seus membros e se encontram expressas em debates intensos nas páginas de todos os jornais de expressão libertária e com circulação no Alentejo. Com expressão num pensamento

\footnotetext{
${ }^{5}$ É o caso, por exemplo, da Voz do Operário em Lisboa, que para além de funcionar como escola, foi durante muito tempo local fundamental para a organização de militantes libertários da cidade e, em fase posterior, de militantes comunistas, ainda hoje em atividade.
} 
crítico, de camaradas que atribuíam à Comuna uma forma cooperativa e a sua impossibilidade real de levar à prática os princípios anarquistas, Gonçalves Correia reage e atribui à Comuna da Luz o objetivo de praticar todo o anarquismo permitido pelas circunstâncias e ainda respondendo à crítica,

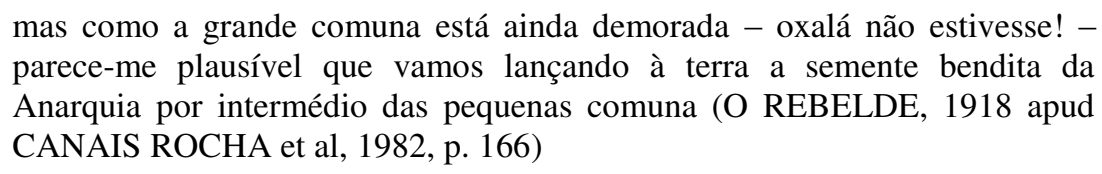

Esta comuna correspondia a uma visão comum de uma corrente anarquista que apesar de ter tido pouca influência em Portugal, teve os seus momentos e os seus protagonistas. Gonçalves Correia foi sem dúvida um desses destacados protagonistas do anarquismo tolstoiano, que colocava questões do modo de vida em paralelo com as questões comuns do sistema produtivo e da exploração da força de trabalho.

No mesmo texto Gonçalves Correia, defende assim a ideia da Comuna:

a comuna emancipa economicamente o produtor e faz-lhe crear consciência
revolucionária. Liberta-o da lei brutal do salário e desenvolve-lhe
esplendidamente os sentimentos de fraternidade, levando-o ao conhecimento
«prático» do lindo ideal que nos aquece a alma. (...) Julgarão camaradas que
uma Comuna não pode ser, com o tempo e boas vontades, uma grande
povoação socialista, progressiva e altruísta? Pois eu julgo isso a coisa mais
natural deste mundo (O REBELDE, 1918 apud CANAIS ROCHA et al,
1982, p. 166)

Da educação como condição fundamental para libertar as massas proletárias, do naturismo ao vegetarianismo, do respeito pelos animais à crítica da instituição do casamento burguês, contrapondo-lhe o amor-livre, a Comuna da Luz foi um exemplo essencial da aspiração dos homens e mulheres do inicio do século XX por uma sociedade mais justa, por liberdade e igualdade. A sua influência ideológica terá sido decisiva nos trabalhadores rurais que ocuparam propriedades durante a greve geral de novembro de 1918 e resistiram durante quatro dias à GNR e às milícias civis dos proprietários rurais. Dessa influência nos dá conta os depoimentos recolhidos por Canais Rocha e Rosalina Labaredas (1982), o relato de Raúl Brandão (1984) e a própria atuação repressivas das forças policiais durante os acontecimentos. Afinal, a semente da subversão lançada pela Comuna da Luz, por Gonçalves Correia e seus camaradas, pode ter influenciado decisivamente os trabalhadores agrícolas que foram protagonistas dos acontecimentos do Vale de Santiago.

O anarquista alentejano apresenta-se na fotografia da edição de "Estreia de um Crente" (CORREIA,1917) com ar sério, bigode enrolado e com a roupa operária que costumava usar no dia-a-dia. Dedica esse trabalho a todos os "rebeldes conscientes" 
como prova do "carinho e do doce afeto" que por eles sente. Ele próprio um rebelde consciente, a vida de Gonçalves Correia parece ter ainda a capacidade de nos transportar ao longo do tempo e de acompanhar os dilemas e momentos fundamentais de uma classe que transportou consigo os dramas e as aspirações de emancipação da humanidade. Pacifista radical que aceitava a violência em situações excepcionais "para evitar males maiores, o seu pensamento esteve sempre em sintonia com um tempo de intensos debates ideológicos, mas sobretudo com práticas em que tentou construir à sua volta condições para a emancipação dos trabalhadores e dos seus filhos. Pretexto útil para pensar a história do trabalho em Portugal no início do século XX e de todos os conflitos sociais que lhe foram próximos, este é o exemplo de um anarquista que procurava no comunismo, a felicidade de todos os seres na sociedade futura, como titulou um seu texto apresentado em conferência e publicado posteriormente, que procurou sempre que a sua vida fosse de acordo com os seus ideais. Sem margem para dúvidas, Gonçalves Correia, foi alguém que fez da utopia uma prática concreta de vida.

\section{Referências bibliográficas}

ASSUNÇÃO, António Rodrigues, O Movimento Operário da Covilhã, Ed. De autor, 2006, Vol. I, 543 p.

BICHO, Francisca, Gonçalves Correia - Abordagem ao seu pensamento I, A Batalha, Lisboa, nov./dez., No 251, 2012, p.3.

BRANDÃO, José, Sidónio- Contribuição para a história do presidencialismo, $\mathrm{P} \& \mathrm{R}$, Lisboa, 1983, 190 p.

BRANDÃO, Raúl, Os Operários, Biblioteca Nacional, Lisboa, 1984, 368 p.

CANAIS ROCHA, Francisco e Labaredas, Rosalina, Os trabalhadores rurais do Alentejo e o Sidonismo - ocupação de terras no Vale de Santiago, Ed. Um de Outubro, Lisboa, 1982, 191 p.

CORREIA, Gonçalves, Carta ao Presidente da República, A Batalha, 21 maio 1920, p.1. 
CORREIA, Gonçalves, Estreia de um Crente, Ed. de autor disponível na Biblioteca Nacional, cota S.C. 7175//10V. (fundo monográfico), 1917.

CORREIA, Gonçalves, Ficheiro da PIDE/DGS SC/SPS 583 Caixa 4291, Torre do Tombo, Lisboa, 1932.

FRANCO, Alberto, A Revolução é a Minha Namorada - memória de António Gonçalves Correia, anarquista alentejano, Câmara Municipal de Castro Verde, 2000, $75 \mathrm{p}$.

LINDEN, Marcel van der, Workers of the world - Essays toward a Global Labor History, Leiden, Boston, 2008, Vol. I, 469 p.

MEDINA, João (apresentação) Portugal na Grande Guerra - Guerristas e Antiguerristas, centro de História da UL, Lisboa, 1986, 139 p.

MEDINA, João, Sidónio, Morte e Transfiguração de Sidónio Pais, Cosmos, Lisboa, 1994, $256 \mathrm{p}$.

PEREIRA, José Pacheco, As lutas sociais dos trabalhadores alentejanos: do banditismo à greve in "O Século XIX em Portugal", colóquio do Gabinete de Investigações Sociais, Presença, Lisboa, 1979.

ROSAS, Fernando; Rolo, Maria Fernanda; (cord.), História da $1^{\text {a }}$ República Portuguesa, Tinta da China, Lisboa, 2009, 611 p.

SAMARA, Maria Alice, Sidónio Pais - Fotobiografias do Século XX, Circulo de Leitores, Rio de Mouro, 2002.

TELO, António José, O Sidonismo e o Movimento Operário Português, Biblioteca Ulmeiro, Lisboa, 1977, 330 p.

THOMPSON, E.P., A Economia Moral da Multidão na Inglaterra do séc. XVIII, Lisboa, Antígona, 2008, 148 p. 